\title{
A Review of Social Commerce Research
}

\author{
Huifen Wang, Jiaxin Xie \\ School of Management, Jinan University, Guangzhou, China \\ Email: jxinxie@163.com
}

How to cite this paper: Wang, H. F., \& Xie, J. X. (2020). A Review of Social Commerce Research. American Journal of Industrial and Business Management, 10, 793-803.

https://doi.org/10.4236/ajibm.2020.104053

Received: March 24, 2020

Accepted: April 19, 2020

Published: April 22, 2020

Copyright (C) 2020 by author(s) and Scientific Research Publishing Inc. This work is licensed under the Creative Commons Attribution International License (CC BY 4.0).

http://creativecommons.org/licenses/by/4.0/

\begin{abstract}
With the development of social networks, social commerce has become a key development model in the field of e-commerce in the future. By sorting out a large amount of relevant literature on social commerce, this paper first reviews the development of the concept of social commerce. Secondly, it analyzes the classification of social commerce and its differences from traditional e-commerce. Finally, a systematic analysis of existing research on consumer behavior (acceptance, purchase, information sharing) of social commerce. This article aims to sort out the current research results, summarize the research characteristics in this field, and point out future research areas and directions worthy of attention.
\end{abstract}

\section{Keywords}

Social Commerce, Concepts, Categories, User Behavior

\section{Introduction}

The development of social networks has brought huge changes to the e-commerce industry. Compared with traditional search-based e-commerce, the discoverybased purchase model has brought higher benefits to merchants. The new-type social commerce enterprises create high-cost-effective products to attract users to share products and group purchase goods through social platforms. In doing so, it not only improves online shopping trust, but also reduces e-commerce drainage costs, and creating a breakthrough for e-commerce development. On the other hand, social platform realizes diversified business model by traffic to liquidate, achieve a win-win both. More and more companies have seen the dividends of social commerce and started to use WeChat, Weibo, Facebook and other social media for product promotion, such as: WeChat payment section, Weibo wallet, etc. E-commerce companies such as Vipshop and Ymatou have settled in social media. This social commerce formed by integrating social media and e-commerce has also become the future electronics Development priorities 
in the business sector.

In addition, the rapid development of social commerce has also attracted the attention of academic circles. Scholars at home and abroad have also obtained rich research results in the field of social electronic commerce (Liu et al., 2017; Zong, 2013). It can be seen that the development and management of social commerce have become the focus of attention of managers and scholars. This paper reviews and sorts out the current research on social commerce at home and abroad, analyzes its research status and potential research areas worthy of attention, with a view to providing a reference for Chinese scholars' follow-up research topics. At the same time, help the social commerce managers to further understand the characteristics of social commerce, and provide a reference for future management activities.

\section{Social Commerce}

At present, the exploration in the field of social commerce has attracted widespread attention in the academic community. This article is mainly based on CNKI, Web of Science, EBSCO, Elsevier and other indexes and full-text databases, and the subject and keywords are used as the retrieval strategy for literature collection. Subject to the search function of academic databases, some related literature information may be excluded from the search results. Therefore, this article uses Google Scholar and other search engines to retrieve auxiliary literature collection. Through the collection and collation of research literature and data related to social commerce at home and abroad, it is found that in recent years, scholars have continued their research on social commerce and the focus of their attention is mainly on the social commerce business model, user adoption behavior, user information sharing behavior, user purchasing behavior, etc. This paper has conducted extensive investigations on relevant literature, and comprehensively and thoroughly combed the current research results of social electronic commerce at home and abroad. As a result, it is found that the research fields of this topic are mainly focused on the following six aspects.

\subsection{Concept of Social Commerce}

With the development of e-commerce, Social Commerce has also developed. In the current research, scholars call it "social commerce", "community e-commerce", "social shopping", etc. Wu et al. (2019) found that "social commerce" has been accepted by scholars in many studies, but so far, there is no uniform definition of the term "social commerce" in academia.

The concept of social commerce was proposed by Yahoo! in 2005, and through the participation of customers of major online companies such as Amazon, Groupon, and eBay, social commerce has quickly become an important part of value-added business services (Zhang \& Wang, 2012). So far, there is no clear definition of what social commerce is. According to Richter et al. (2007), social 
commerce emphasizes interpersonal relationships and interactions (product evaluation, product information exchange and feedback), and plays an important role during and after commercial transactions. Afrasiabi Rad \& Benyoucef (2011) believe that social commerce is a special type of e-commerce based on personalized and interactive social relationships. Scholars such as Hargadon \& Bechky (2006), Hajli (2014), Kim \& Park (2013) believe that social commerce is a new form of e-commerce, which allows consumers to create content through social interaction to reach different product markets. Research by Liang \& Turban (2011) pointed out that social media uses Web 2.0 applications to support users' online interactions and access to services and products, distinguishing social commerce from traditional e-commerce. Kang \& Park (2009) believe that social commerce is a new type of e-commerce that emphasizes the possibility for users to discuss and evaluate goods or services. Dennison et al. (2009) clearly puts forward: Social commerce is based on Web 2.0 technology, using users to create content and social network relationships to promote users to purchase products and services. According to domestic scholar Zong (2013), social commerce is a business model that promotes and sells products or services by integrating social graph (interaction based on interpersonal relationship) and interest graph (interaction based on information flow) in the context of social media.

Based on the previous research, this paper makes the definition of social commerce: social commerce is the use of social media, social media, online media and other communication channels in the context of social media, it is a new type of e-commerce that use social media technology to conduct interpersonal relationships and business information flow Interaction and assists the purchase and sales of goods through social interaction and user-generated content.

\subsection{The Difference between Social Commerce and Traditional E-Commerce}

Afrasiabi Rad \& Benyoucef (2011) proposed that social commerce is developed from "one-to-one interaction" e-commerce, with more social attributes and social interaction. Compared with traditional e-commerce, social commerce pays more attention to network, collaboration, information sharing and other elements, followed by sales (Gatautis \& Medziausiene, 2014). Wang \& Zhang (2012) made a comparative analysis of the development of social commerce from four dimensions of interpersonal relationship, management, technology and information. Geng (2017) pointed out that compared with traditional e-commerce, social commerce has the characteristics of low traffic acquisition cost, high purchase conversion rate, accurate marketing and large user stickiness, etc. The main differences are concentrated in the three aspects of business objectives, customer relationship and system interaction.

Combining with the research of existing scholars, this paper will summarize the differences between social commerce and traditional e-commerce from the following five aspects, as shown in Table 1. 
Table 1. The difference between social commerce and traditional e-commerce.

\begin{tabular}{|c|c|c|}
\hline Dimension & Traditional e-commerce & Social commerce \\
\hline $\begin{array}{l}\text { Interpersonal } \\
\text { interaction }\end{array}$ & $\begin{array}{l}\text { The main form of interpersonal } \\
\text { interaction in traditional e-commerce } \\
\text { is online commodity review. }\end{array}$ & $\begin{array}{l}\text { Social commerce takes interpersonal } \\
\text { interaction as the core of development } \\
\text { and carries out further business activities } \\
\text { based on the social network formed by } \\
\text { users. }\end{array}$ \\
\hline Social media & $\begin{array}{l}\text { Traditional e-commerce has fewer } \\
\text { social media functions. }\end{array}$ & $\begin{array}{l}\text { Social commerce is the result of } \\
\text { e-commerce superimposed by social } \\
\text { media. By adding community functions } \\
\text { that support social communication and } \\
\text { interaction, social commerce promotes } \\
\text { the dialogue among users. Its core } \\
\text { business activities are mainly dominated } \\
\text { by social media. }\end{array}$ \\
\hline $\begin{array}{l}\text { Business } \\
\text { intention }\end{array}$ & $\begin{array}{l}\text { Traditional e-commerce focuses on } \\
\text { presentation of product information } \\
\text { and price advantage, to sales as a key } \\
\text { measure, to maximize the purchase } \\
\text { rate is the core of business objectives. }\end{array}$ & $\begin{array}{l}\text { Social commerce pays attention to the } \\
\text { user's interaction, cooperation, and user } \\
\text { generated content, allow the user to be } \\
\text { the designer and the seller, not only the } \\
\text { recipient, social goal is its core business } \\
\text { objectives. }\end{array}$ \\
\hline $\begin{array}{l}\text { Information } \\
\text { flow }\end{array}$ & $\begin{array}{l}\text { Traditional e-commerce emphasizes } \\
\text { "broadcast" information diffusion, } \\
\text { and its content generation is a } \\
\text { one-way process, information rarely } \\
\text { from a customer to enterprises or } \\
\text { other customers. }\end{array}$ & $\begin{array}{l}\text { Social commerce emphasizes user } \\
\text { contributions and user-generated } \\
\text { content. Through the permeable } \\
\text { information exchange among users, it can } \\
\text { improve the trust of users and enhance } \\
\text { the persuasiveness and dis-semination of } \\
\text { information. }\end{array}$ \\
\hline System design & $\begin{array}{l}\text { Traditional e-commerce systems are } \\
\text { designed to show the characteristics of } \\
\text { products or services, information } \\
\text { retrieval technology is the key, such as } \\
\text { search and navigation. }\end{array}$ & $\begin{array}{l}\text { Social commerce focuses on the user and } \\
\text { community interface, with comments, } \\
\text { conversations, ratings and other core } \\
\text { functions. }\end{array}$ \\
\hline
\end{tabular}

a. Source: concluded by this study.

\subsection{Classification of Social Commerce}

With the development of network technology and social media, there are more and more different modes of social e-commerce. Scholars have classified social e-commerce according to different business models, activity subjects, business priorities, operation modes, etc. This paper sorts out the research results on the classification of social e-commerce by combing the existing researches of scholars. The details are shown in Table 2.

\subsection{Factors Influencing User Acceptance in Social Commerce}

Since Davis (1993) put forward the Technology Acceptance Model (TAM), many scholars have used TAM to study the Acceptance behavior of information systems, and at the same time, TAM models in different fields have not been enriched and expanded in many ways. In 2003, Venkatesh et al. (2003) proposed an integrated and unified Technology Acceptance Model (TAM) applicable to 
Table 2. Classification of social commerce.

\begin{tabular}{|c|c|c|c|}
\hline Classification criteria & Category & $\begin{array}{l}\text { Typical } \\
\text { representative }\end{array}$ & References \\
\hline Business model & $\begin{array}{l}\text { Socialization of traditional business } \\
\text { E-commerce marketing with social media } \\
\text { Commercialization of social media }\end{array}$ & $\begin{array}{l}\text { Taobao, Amazon } \\
\text { WeChat, Weibo } \\
\text { Mogu Street, } \\
\text { MeiLiShuo }\end{array}$ & Wang \& Zhang (2012) \\
\hline $\begin{array}{l}\text { Activity subject } \\
\text { category }\end{array}$ & $\begin{array}{l}\text { B2C website self-built community } \\
\text { Electronic business platform } \\
\text { Portal and Vertical Media } \\
\text { Comprehensive SNS community and Weibo } \\
\text { Emerging Shopping Social Site }\end{array}$ & $\begin{array}{l}\text { Mbaobao } \\
\text { Tencent Q-Zone } \\
\text { iStyle } \\
\text { Renren, Weibo } \\
\text { Mogu Street }\end{array}$ & Yu (2015) \\
\hline Business focus & $\begin{array}{l}\text { Social commerce based on social media } \\
\text { Social commerce based on e-commerce community platform } \\
\text { Third party social e-commerce }\end{array}$ & $\begin{array}{l}\text { Facebook, Weibo } \\
\text { Vancl Star } \\
\text { Xiaohongshu }\end{array}$ & \\
\hline Display form & $\begin{array}{l}\text { Social commerce based on interest social model } \\
\text { Social commerce based on the Pinterest model } \\
\text { Social commerce based on media shopping guide model } \\
\text { Social e-commerce based on O2O model }\end{array}$ & $\begin{array}{l}\text { Xiaohongshu } \\
\text { Mogu Street } \\
\text { huihui.cn } \\
\text { Dianping, WeChat }\end{array}$ & Zhu \& Chen (2016) \\
\hline $\begin{array}{l}\text { Traffic acquisition metl } \\
\text { and operating models }\end{array}$ & $\begin{array}{l}\text { Shopping pool social commerce } \\
\text { s Membership social commerce } \\
\text { Community group-buying social commerce } \\
\text { Content social commerce }\end{array}$ & $\begin{array}{l}\text { Pinduoduo } \\
\text { Yunji, Beidian } \\
\text { Songshupinpin } \\
\text { Xiaohongshu, Tik Tok }\end{array}$ & Wang (2019) \\
\hline
\end{tabular}

a. Source: concluded by this study.

the adoption of most information systems in response to users' information adoption behavior. Similarly, TAM is also suitable for information systems such as social commerce. Scholars have further expanded TAM based on the characteristics of social commerce. Kang \& Park (2009) studied the users of social shopping websites in South Korea and found that hedonism, social motivation, perceived usefulness, perceived ease of use, age characteristics, interests and income levels, etc. had a significant impact on users' social commerce use behavior. The research of Liang et al. (2011) and Yang (2014) both pointed out that social support and website quality positively affected users' willingness and behavior to use social commerce. Through the questionnaire survey, Teh \& Ahmed (2011) found that consumption motivation, consumption ability and operation standardization have a positive impact on users' acceptance of social commerce. The research results of Ju (2012) show that the security, integrity, empathy and interaction of social commerce will affect the usefulness, ease of use and perceived risks, and then affect users' willingness to use.

Based on the above research results, TAM is still an important research model of social commerce users' acceptance behavior. However, it is not enough to only consider the two factors of perceived ease of use and perceived usefulness. In combination with the social characteristics of social commerce, scholars have integrated hedonism, altruism and other factors into the model. The exploration of the social nature of commerce has become the focus of research in this field. 


\subsection{Factors Influencing User Purchase in Social Commerce}

The ultimate goal of the development of social commerce is still to promote the purchase behavior of users, and the purchase behavior is affected by the purchase intention, so the factors that influence the purchase intention of users are an important part of the research in the field of social commerce. From the review results of the existing literature, at present, the research on the purchase intention of social commerce mainly discusses the purchase intention of users from the aspects of information technology, trust, perceived value, and social relations.

1) The impact of information technology on users' use of social commerce. Dong \& Wang (2018) found that the perceived effectiveness of the social commerce system mechanism has a positive regulating effect on the formation of strong connection, thus promoting the purchase intention of users. The research results indicate that the interaction of social commerce is an important factor influencing the formation of strong connection. Chong et al. (2018) found that perceiving the effectiveness of the e-commerce institutional mechanism would negatively regulate users' trust in online sellers and repurchase intentions.

2) The influence of trust on the purchase intention of users. Hajli (2012) built social commerce acceptance model (SCAM) by combining trust and perceived usefulness, and found that friend recommendation, community content, user comments, etc., all affect the trust intensity. Yahia et al. (2018) pointed out that the characteristics of suppliers in social commerce would affect users' willingness to conduct social business, among which the reputation and price advantage of suppliers had the greatest impact on trust, while habits would weaken these impacts. Lu et al. (2016) studied the relationship between social telepresence, trust and purchase intention, and found that the social telepresence of the network and the social telepresence of the interaction with the seller would affect users' trust in the seller, thus affecting users' purchase intention.

3) The influence of perceived value on the purchase intention of users. Mamonov \& Benbunan-Fich (2017) found that low perceived value would negatively affect users' purchase behavior in social commerce. Lee et al. (2016) pointed out that trust, low price, website reputation, experience value and so on will affect customers' perceived price, and then affect users' purchase intention. Yun (2011) explored users' social shopping motivations and shopping objectives, and found that perceived value was significantly affected by perceived credibility of information and social resources, and moderately affected by social shopping motivations. What's more, perceived value significantly affects behavioral intention. And, perceived self-efficacy is an intermediary between perceived value and behavioral intention.

4) The influence of social relations on users' purchase intention. According to Sun et al. (2016), social commerce mainly influences the purchase behavior of users through social networks, and high-quality social atmosphere of group members will positively influence the purchase behavior of members. Zhang 
(2014) pointed out that the increase of interaction between users and between users and the platform has a positive impact on promoting continuous use of users. Harris \& Dennis (2011) believe that friend recommendation has a significant impact on users' online shopping habits and is related to the trust between friends.

\subsection{Factors Influencing User Information Sharing in Social Commerce}

For social commerce enterprises, user-generated content is of great significance in terms of product value dissemination, product demand guidance, and user attraction. In the process of sorting out the existing literature, this paper finds that the current research results on users' willingness to share information in social commerce are relatively scarce. This paper summarizes the relevant research in order to provide theoretical guidance for the follow-up research on the factors influencing the users' willingness to share information. Specific research results are summarized in Table 3.

After sorting out the research results of users' willingness to share information in social e-commerce at home and abroad, it is found that the existing research mainly focuses on the exploration of the relationship between social factors and information sharing willingness. Among them, psychological factors such as trust and hedonism are also the focus of this research. The privacy protection in social electronic commerce has also attracted more and more attention from scholars. In addition, after combing the results, it is found that the current related research mainly uses empirical analysis methods with questionnaires as the core, and the research methods are relatively simple and have limitations.

\section{Discussion and Implications}

At present, the research on social e-commerce has entered the mature stage of development. However, there is no unified definition of the concept of social e-commerce. Scholars have systematically classified social e-commerce according to different business models and business priorities. In this article, through reviewing and combing the existing research results, found that the present social commerce research mainly has the following characteristics: 1) the research content, the current domestic and foreign relevant social e-commerce user behavior research mainly focused on the (intention) accept behavior and purchasing behavior (intention) two aspects, the user information about the socialization of the electronic commerce environment sharing behavior (intention) research is not much. The theoretical basis of the research mainly includes psychological change mechanism, information technology adoption, marketing, communication and so on. 2) in terms of research methods, the research on user acceptance and purchase behavior mainly adopts the empirical analysis method based on questionnaire survey. The research method is relatively simple and lacks the exploration of qualitative research, which has its limitations. 
Table 3. Research results on the willingness and behavior of social commerce users to share information.

\begin{tabular}{|c|c|c|c|}
\hline Research perspective & $\begin{array}{l}\text { Research } \\
\text { method }\end{array}$ & Research result & References \\
\hline Social capital & $\begin{array}{l}\text { Empirical } \\
\text { analysis }\end{array}$ & $\begin{array}{l}\text { Social capital has a significant positive } \\
\text { effect on users' willingness to participate } \\
\text { in social commerce. }\end{array}$ & $\begin{array}{l}\text { Horng \& Wu } \\
(2020)\end{array}$ \\
\hline $\begin{array}{l}\text { Social capital, } \\
\text { Social interaction }\end{array}$ & $\begin{array}{l}\text { Empirical } \\
\text { analysis }\end{array}$ & $\begin{array}{l}\text { Social capital and social interaction will } \\
\text { promote the information sharing of users, } \\
\text { thus promoting the purchase intention. }\end{array}$ & $\begin{array}{l}\text { Ghahtarani } \\
\text { et al. (2019) }\end{array}$ \\
\hline $\begin{array}{l}\text { Social support, } \\
\text { Community factor }\end{array}$ & $\begin{array}{l}\text { Empirical } \\
\text { analysis }\end{array}$ & $\begin{array}{l}\text { Social support, community recognition } \\
\text { and community trust will affect user } \\
\text { stickiness and user's intention to } \\
\text { purchase, create value and release } \\
\text { positive word of mouth. }\end{array}$ & $\begin{array}{l}\text { Molinillo et al. } \\
\text { (2019) }\end{array}$ \\
\hline Trust & $\begin{array}{l}\text { Empirical } \\
\text { analysis }\end{array}$ & $\begin{array}{l}\text { Both person-to-person interaction and } \\
\text { human-computer interaction have a } \\
\text { significant impact on trust, which in } \\
\text { turn affects users' purchase intention } \\
\text { and sharing intention. }\end{array}$ & $\begin{array}{l}\text { Fang \& Zhou } \\
(2017)\end{array}$ \\
\hline $\begin{array}{l}\text { Internal and external } \\
\text { revenue factors, Cost } \\
\text { factors }\end{array}$ & $\begin{array}{l}\text { Empirical } \\
\text { analysis }\end{array}$ & $\begin{array}{l}\text { External reward, image enhancement, } \\
\text { reciprocal relationship, helpfulness, } \\
\text { criticism, fear and time cost all affect } \\
\text { users' willingness to share information. } \\
\text { Among them, different dimensions of } \\
\text { the big five personalities have different } \\
\text { adjustment effects on different external } \\
\text { benefit and cost factors. }\end{array}$ & $\begin{array}{l}\text { Liu et al. } \\
\text { (2017) }\end{array}$ \\
\hline $\begin{array}{l}\text { Technology acceptance } \\
\text { model, Immersion } \\
\text { theory }\end{array}$ & $\begin{array}{l}\text { Empirical } \\
\text { analysis }\end{array}$ & $\begin{array}{l}\text { Social trust, perceived ease of use, } \\
\text { hedonic motivation and external } \\
\text { rewards significantly positively affect } \\
\text { user-generated content behavior. }\end{array}$ & $\begin{array}{l}\text { Meng \& Jiang } \\
(2015)\end{array}$ \\
\hline $\begin{array}{l}\text { Privacy trade-offs, } \\
\text { Social interaction }\end{array}$ & $\begin{array}{l}\text { Empirical } \\
\text { analysis }\end{array}$ & $\begin{array}{l}\text { Privacy protection (privacy policy, } \\
\text { privacy settings) and social interactions } \\
\text { (including information interactions, } \\
\text { emotional interactions) significantly } \\
\text { affect privacy risks and social returns, } \\
\text { and then determine the user's social } \\
\text { business willingness (including sharing } \\
\text { and purchase). }\end{array}$ & $\begin{array}{l}\text { Zhou et al. } \\
\text { (2019) }\end{array}$ \\
\hline
\end{tabular}

a. Source: concluded by this study.

Combined with the above analysis, this paper believes that, in terms of research content, the future research in the field of social e-commerce will focus on the analysis of user behavior (intention), among which the social factor is the key factor, and the future can be more based on the sociological theory to explore user behavior. In terms of research methods, scholars can consider qualitative research methods, such as simulation and interview. Empirical mixed with the combination of qualitative research methods, also will be the development 
trend of future study, this method can make the researchers more intuitive understanding of the social e-commerce user's real ideas, avoid deviation survey data, more suitable for the studies of social factors and psychological factors and so on, is advantageous to the scholars to study comprehensively and objectively.

\section{Conclusion}

This research collects, sorts and reviews the current research results of social commerce at home and abroad, and analyzes and discusses the main research models and factors of the concept, characteristics, and user participation behavior of social commerce. Summarized the existing research results, and proposed possible future research trends and key points. We think this research will be valuable to researchers and managers of social commerce. Since social commerce is still developing at a high speed, the review in this article provides a theoretical basis for researchers and is conducive to their future research and innovation.

\section{Conflicts of Interest}

The authors declare no conflicts of interest regarding the publication of this paper.

\section{References}

Afrasiabi Rad, A., \& Benyoucef, M. (2011). A Model for Understanding Social Commerce. Journal of Information Systems Applied Research, 4, 63.

Chong, A. Y. L., Lacka, E., Boying, L., \& Chan, H. K. (2018). The Role of Social Media in Enhancing Guanxi and Perceived Effectiveness of E-Commerce Institutional Mechanisms in Online Marketplace. Information \& Management, 55, 621-632. https://doi.org/10.1016/j.im.2018.01.003

Davis, F. D. (1993). User Acceptance of Information Technology: System Characteristics, User Perceptions and Behavioral Impacts. International Journal of Man-Machine Studies, 38, 475-487. https://doi.org/10.1006/imms.1993.1022

Dennison, G., Bourdage-Braun, S., \& Chetuparambil, M. (2009). Social Commerce Defined. White Paper, 23747.

Dong, X., \& Wang, T. (2018). Social Tie Formation in Chinese Online Social Commerce: The Role of IT Affordances. International Journal of Information Management, 42, 49-64. https://doi.org/10.1016/j.ijinfomgt.2018.06.002

Fang, W. K., \& Zhou, T. (2017). The Effect of Social Interaction on Social Commerce User Behaviour. Journal of Intelligence, 36, 167-172.

Gatautis, R., \& Medziausiene, A. (2014). Factors Affecting Social Commerce Acceptance in Lithuania. Procedia-Social and Behavioral Sciences, 110, 1235-1242.

https://doi.org/10.1016/j.sbspro.2013.12.970

Geng, R. N. (2017). Research on Information Adoption Process and Influence Factors of Social E-Commerce User. Ph.D. Thesis, Changchun: Jilin University.

Ghahtarani, A., Sheikhmohammady, M., \& Rostami, M. (2019). The Impact of Social Capital and Social Interaction on Customers' Purchase Intention, Considering Knowledge Sharing in Social Commerce Context. Journal of Innovation \& Knowledge. 
https://doi.org/10.1016/j.jik.2019.08.004

Hajli, M. (2012). Social Commerce Adoption Model. In UKAIS (pp. 16).

Hajli, M. N. (2014). A Study of the Impact of Social Media on Consumers. International Journal of Market Research, 56, 387-404. https://doi.org/10.2501/IJMR-2014-025

Hargadon, A. B., \& Bechky, B. A. (2006). When Collections of Creatives Become Creative Collectives: A Field Study of Problem Solving at Work. Organization Science, 17, 484-500. https://doi.org/10.1287/orsc. 1060.0200

Harris, L., \& Dennis, C. (2011). Engaging Customers on Facebook: Challenges for e-Retailers. Journal of Consumer Behaviour, 10, 338-346. https://doi.org/10.1002/cb.375

Horng, S. M., \& Wu, C. L. (2020). How Behaviors on Social Network Sites and Online Social Capital Influence Social Commerce Intentions. Information \& Management, 57, Article ID: 103176. https://doi.org/10.1016/j.im.2019.103176

Ju, X. (2012). Research on User Acceptance of Social Commerce. Ph.D. Thesis, Beijing: Beijing University of Posts and Telecommunications.

Kang, Y. R., \& Park, C. (2009). Acceptance Factors of Social Shopping. In Proceedings of the 2009 11th International Conference on Advanced Communication Technology (Vol. 3, pp. 2155-2159). South Korea.

Kim, S., \& Park, H. (2013). Effects of Various Characteristics of Social Commerce (s-Commerce) on Consumers' Trust and Trust Performance. International Journal of Information Management, 33, 318-332. https://doi.org/10.1016/j.ijinfomgt.2012.11.006

Lee, Y. K., Kim, S. Y., Chung, N., Ahn, K., \& Lee, J. W. (2016). When Social Media Met Commerce: A Model of Perceived Customer Value in Group-Buying. Journal of Services Marketing, 30, 398-410. https://doi.org/10.1108/JSM-04-2014-0129

Liang, T. P., \& Turban, E. (2011). Introduction to the Special Issue Social Commerce: A Research Framework for Social Commerce. International Journal of Electronic Commerce, 16, 5-14. https://doi.org/10.2753/JEC1086-4415160201

Liang, T. P., Ho, Y. T., Li, Y. W., \& Turban, E. (2011). What Drives Social Commerce: The Role of Social Support and Relationship Quality. International Journal of Electronic Commerce, 16, 69-90. https://doi.org/10.2753/JEC1086-4415160204

Liu, R. J., Cao, H. F., \& Liu, L. L. (2017). An Empirical Study on Psychological Factors of Information Sharing in Social Commerce Websites. Soft Science, 31, 101-107.

Lu, B., Fan, W., \& Zhou, M. (2016). Social Presence, Trust, and Social Commerce Purchase Intention: An Empirical Research. Computers in Human Behavior, 56, 225-237. https://doi.org/10.1016/j.chb.2015.11.057

Mamonov, S., \& Benbunan-Fich, R. (2017). Exploring Factors Affecting Social e-Commerce Service Adoption: The Case of Facebook Gifts. International Journal of Information Management, 37, 590-600. https://doi.org/10.1016/j.ijinfomgt.2017.05.005

Meng, J., \& Jiang, Y. (2015). Motivation of User Generated Content in Social Commerce Environment-A Case Study of Dianping.com. Journal of Modern Information, 35, 31-37.

Molinillo, S., Anaya-Sánchez, R., \& Liébana-Cabanillas, F. (2019). Analyzing the Effect of Social Support and Community Factors on Customer Engagement and Its Impact on Loyalty Behaviors toward Social Commerce Websites. Computers in Human Behavior, 2019, Article ID: 105980. https://doi.org/10.1016/j.chb.2019.04.004

Richter, A., Koch, M., \& Krisch, J. (2007). Social commerce: Eine Analyse des Wandels im E-commerce. Munich: Fak. für Informatik, Universität der Bundeswehr München.

Sun, Y., Lu, Y. B., \& Wei, G. J. (2016). Social Commerce: The Impact of Social Climate on Friendship Group Members Purchase Intention and Behavior. Chinese Journal of 
Management, 13, 1392.

Teh, P. L., \& Ahmed, P. K. (2011). MOA and TRA in Social Commerce: An Integrated Model. In 2011 IEEE International Conference on Industrial Engineering and Engineering Management (pp. 1375-1379). Singapore. https://doi.org/10.1109/IEEM.2011.6118141

Venkatesh, V., Morris, M. G., Davis, G. B., \& Davis, F. D. (2003). User Acceptance of Information Technology: Toward a Unified View. MIS Quarterly, 27, 425-478. https://doi.org/10.2307/30036540

Wang, C., \& Zhang, P. (2012). The Evolution of Social Commerce: The People, Management, Technology, and Information Dimensions. Communications of the Association for Information Systems, 31, 105-127. https://doi.org/10.17705/1CAIS.03105

Wang, L. (2019). Analysis of the Development Status of China's Social e-Commerce Industry. The Internet Economy, 2.

Wu, G. D., Wu, Z., Ding, X. W., \& Xia, Z. J. (2019). A Visual Analysis of Domestic Social Business Research from the Perspective of Knowledge Mapping. Management Modernization, 1, 86-91.

Yahia, I. B., Al-Neama, N., \& Kerbache, L. (2018). Investigating the Drivers for Social Commerce in Social Media Platforms: Importance of Trust, Social Support and the Platform Perceived Usage. Journal of Retailing and Consumer Services, 41, 11-19. https://doi.org/10.1016/j.jretconser.2017.10.021

Yang, L. P. (2014). Empirical Research on Consumer Adoption of Social Commerce. Ph.D. Thesis, Beijing: Beijing University of Posts and Telecommunications.

Yu, J. L. (2015). Development Status and Mode Selection of Social E-Commerce. Business, No. 15, 102-102.

Yun, Z. S. (2011). Testing a Theoretical Model to Examine the Relationships among e-Social Shopping Motivation, Perception, and Behavioral Intention. East Lansing, MI: Michigan State University.

Zhang, H. (2014). The Study on Customers' Interaction Behavior in Social Commerce. Ph.D. Thesis, Wuhan: Huazhong University of Science and Technology.

Zhang, P., \& Wang, C. (2012). The Evolution of Social Commerce: An Examination from the People, Business, Technology, and Information Perspective. https://doi.org/10.17705/1CAIS.03105

Zhou, T., Zhen, H. Y., \& Deng, S. L. (2019). On Effect of Privacy Risk on Socialized Commerce Users' Behaviours. Journal of Hangzhou Dianzi University (Social Sciences), 15, 7-13.

Zhu, X. D., \& Chen, J. (2016). Summary of Social E-Commerce Research in China. Journal of Modern Information, 36, 172-177.

Zong, Q. J. (2013). A Review of Social Commerce Research. Journal of Intelligence, 32, $117-121$. 